\author{
Marek Chrabkowski \\ Wyższa Szkoła Administracji i Biznesu, Gdynia \\ m.chrabkowski@wsaib.pl
}

\title{
Gwarancja bankowa jako przedmiot czynności wykonawczej w oszustwie kredytowym
}

DOI: http://dx.doi.org/10.12775/SIT.2017.003

\section{Wstęp}

Przestępstwo oszustwa kredytowego przewidzianego w art. 297 $\S 1$ Ustawy z 6 czerwca 1997 r. - Kodeks karny ${ }^{1}$ zostało zamieszczone w rozdziale XXXVI pt. „Przestępstwa przeciwko obrotowi gospodarczemu". Zgodnie $z$ brzmieniem tego przepisu, kto, w celu uzyskania dla siebie lub kogo innego, od banku lub jednostki organizacyjnej prowadzącej podobną działalność gospodarczą na podstawie ustawy albo od organu lub instytucji dysponujących środkami publicznymi - kredytu, pożyczki pieniężnej, poręczenia, gwarancji, akredytywy, dotacji, subwencji, potwierdzenia przez bank zobowiązania wynikającego $\mathrm{z}$ poręczenia lub z gwarancji lub podobnego świadczenia pieniężnego na określony cel gospodarczy, instrumentu płatniczego lub zamówienia publicznego, przedkłada podrobiony, przerobiony, poświadczający nieprawdę albo nierzetelny dokument albo nierzetelne pisemne oświadczenie dotyczące okoliczności o istotnym znaczeniu dla uzyskania wymienionego wsparcia finansowego, instrumentu płatniczego lub zamówienia, podlega karze pozbawienia wolności od 3 miesięcy do lat 5. Przed-

1 Tekst jednolity: Dz.U. z 2016 r. Poz. 1137, ze zm. 
miotem czynności wykonawczej oszustwa kredytowego może więc być nie tylko kredyt czy pożyczka pieniężna, ale również poręczenie, akredytywa, dotacja, subwencja, potwierdzenie przez bank zobowiązania wynikającego $z$ poręczenia lub $z$ gwarancji lub podobnego świadczenia pieniężnego na określony cel gospodarczy, instrument płatniczy, zamówienie publiczne lub gwarancja w tym także gwarancja bankowa. Autorzy licznych komentarzy do przepisu art. 297 $\S 1$ k.k. swoje rozważania koncentrują na sprawach kredytowych, pomijając całkowicie problematykę gwarancji bankowych lub poprzestając jedynie na zdefiniowaniu tego instrumentu finansowego. Różnice, które występują pomiędzy mechanizmami kredytowymi i gwarancyjnymi, nie pozwalają na bezpośrednie stosowanie rozwiązań pasujących do jednego $z$ tych instrumentów finansowych do drugiego. Umowa kredytowa jest umową dwustronnie zobowiązującą, a umowa gwarancji bankowej - jednostronnie zobowiązującą. W przypadku wymienionej jako ostatnia, występują aż trzy podmioty, których role określone są przepisami prawa. Bank udziela gwarancji na wniosek dłużnika, a środki finansowe uruchamia na żądanie wierzyciela. Nieprawidłowości mogą więc wystąpić na dwóch etapach:

- pierwszym, dotyczącym udzielenia gwarancji, na którym to etapie występuje klient zabiegający w banku (u gwaranta) o udzielenie mu gwarancji bankowej;

- drugim, dotyczącym procedury uruchamiania środków zabezpieczonych umową gwarancji bankowej, w którym to etapie udział bierze gwarant (bank) i beneficjent gwarancji, który jest wierzycielem w stosunku do klienta banku.

Pozytywne zakończenie etapu pierwszego wywołuje zobowiązanie po stronie banku o charakterze pozabilansowym, a uruchomienie środków wynikających $z$ gwarancji bankowej na żądanie beneficjenta uszczupla aktywa banku, wywołując zmianę bilansową. Natomiast w procedurze kredytowej nie występuje faza zobowiązań pozabilansowych. Procedura kredytowa jest jednoetapowa i jej pozytywne zakończenie ma po stronie banku charakter zobowiązania bilansowego. Wypłata środków z tytułu udzielonego kredytu, pomniejsza stan środków finansowych banku i zwiększa aktywa po stronie należności. Te różnice wymagają odrębnego przedstawienia 
i zasygnalizowania rozbieżności w zakresie kwalifikowania przestępnych zachowań, których celem są odmienne przedmioty czynności wykonawczych. Problematyka odpowiedzialności $z$ tytułu oszustwa kredytowego, o którym mowa w art. 297 § 1 k.k. w związku z zawieraniem umowy kredytowej, została szczegółowo omówiona przez przedstawicieli doktryny i wydaje się, że nie wymaga dodatkowego pogłębienia. W ramach tej publikacji poruszone zostanie zagadnienie oszustwa kredytowego, o którym mowa w art. 297 § 1 k.k. przy zawieraniu i wykonaniu umowy gwarancji bankowej, któremu do tej pory nie poświęcono w literaturze przedmiotu należnej uwagi.

Celem badań było udzielenie odpowiedzi na zamieszczone poniżej pytania badawcze:

1. Czy znamię przestępstwa dotyczące „uzyskania gwarancji”, o którym mowa w art. 297 § 1 k.k., odnosi się tylko do etapu poprzedzającego zawarcie umowy gwarancji bankowej, czy też dotyczy również etapów późniejszych i obejmuje swoimi granicami uzyskanie środków finansowych przez beneficjenta z tytułu gwarancji bankowej?

2. Czy podmiotem przestępstwa $z$ art. $297 \S 1$ k.k. może być tylko dłużnik zabiegający w banku o uzyskanie gwarancji bankowej, czy także wierzyciel - beneficjent gwarancji bankowej, którego interesy były tą gwarancją zabezpieczone?

$\mathrm{W}$ związku z postawionymi pytaniami badawczymi przyjęto następujące hipotezy:

1. „uzyskanie gwarancji” jako znamię przestępstwa, o którym mowa w art. $297 \S 1$ k.k., odnosi się do etapu poprzedzającego zawarcie umowy gwarancji bankowej, a ewentualne nieprawidłowości po uzyskaniu tejże gwarancji, na późniejszych etapach związanych $z$ wykonywaniem umowy statuującej ten rodzaj zabezpieczenia, nie mogą być uznane za działania podjęte w celu uzyskania gwarancji;

2. podmiotem przestępstwa $z$ art. $297 \S 1$ k.k. może być tylko dłużnik zabiegający w banku o uzyskanie gwarancji bankowej;

3. podmiotem przestępstwa $z$ art. $297 \S 1$ k.k. nie może być wierzyciel, którego interesy zostały zabezpieczone, ponieważ to nie on zabiega o uzyskanie gwarancji bankowej. 
Przyjęte hipotezy zdeterminowały strukturę publikacji. W artykule przedstawiono w odrębnych podrozdziałach zagadnienia dotyczące:

- zagadnień prawnych i terminologii dotyczących umowy gwarancji bankowej;

- nieprawidłowości na etapie zabiegania o ustanowienie gwarancji bankowej;

- nieprawidłowości na etapie żądania wypłaty środków z tytułu gwarancji bankowej.

Badania przeprowadzono $z$ wykorzystaniem metod badawczych w postaci: krytycznej analizy literatury, badania prawa i badania dokumentów w formie analizy orzecznictwa sądowego. Wnioski z przeprowadzonych badań zostały zawarte w zakończeniu.

\section{Umowa gwarancji bankowej}

Definiując pojęcie „gwarancji bankowej”, w pierwszej kolejności należy sięgnąć do przepisów Ustawy z 29 sierpnia 1997 r. Prawo bankowe $^{2}$. Zgodnie $z$ art. 84 tejże ustawy do gwarancji bankowych stosuje się przepisy Ustawy z 23 kwietnia 1964 r. - Kodeks cywilny $^{3}$. W przepisie tym zastrzeżono jednak, że zobowiązanie banku $z$ tytułu gwarancji jest zawsze zobowiązaniem pieniężnym. Zgodnie $z$ tą regulacją do gwarancji zastosowanie mają nie tylko przepisy odnoszące się umów gwarancyjnych, lecz także te, które zawarte są w części ogólnej Kodeksu cywilnego i normujące zobowiązania w ogólności, odnoszące się do tego typu zobowiązañ ${ }^{4}$. Na podstawie art. 391 k.c., jeżeli w umowie zastrzeżono, że osoba trzecia zaciągnie określone zobowiązanie albo spełni określone świadczenie, ten, kto takie przyrzeczenie uczynił (gwarant), odpowiedzialny jest za szkodę, którą druga strona (beneficjent, uprawniony $z$ gwarancji) ponosi przez to, że osoba trzecia odmawia zaciągnięcia zobowiązania albo nie spełnia świadczenia. Jak trafnie podkreśla się w doktrynie,

2 Tekst jednolity: Dz.U. z 2016 r. Poz. 1988, ze zm.

3 Tekst jednolity: Dz.U. z 2016 r. Poz. 380, ze zm.

4 Szerzej G. Sikorski, Prawo bankowe. Komentarz, Warszawa 2015, art. 81. 
naprawienie szkody, expressis verbis wskazane w tym przepisie, jest pierwotnym i zasadniczym obowiązkiem wynikającym wprost $z$ omawianej umowy, a od tej odpowiedzialności gwarant może się zwolnić, spełniając przyrzeczone świadczenie ${ }^{5}$.

Zobowiązanie $z$ tytułu gwarancji bankowej $w$ momencie jego powstania nie wiąże się $z$ faktycznym przepływem pieniądza, ale stwarza ryzyko wystąpienia takiego przepływu w przyszłości. Stanowi zobowiązanie pozabilansowe banku. Inaczej wygląda to przy umowie kredytowej, która kreuje stosunki zobowiązaniowe wywołujące zmiany w bilansie banku, ponieważ od razu albo w krótkim odstępie czasowym umowa ta wiąże się z przepływem finansowym. Dodatkowo, w przypadku gwarancji bankowej na pierwszy plan wysuwa się jego niemajątkowa funkcja, polegająca na poprawie wiarygodności oblata (dłużnika) w oczach oferenta czy też dłużnika w oczach wierzyciela. Skoro instytucja zaufania publicznego, obracająca znaczącym kapitałem, gwarantuje rzetelność określonego podmiotu gospodarczego i jest skłonna pokryć jego zobowiązania z własnych środków, może to oznaczać dla oferenta, że warto z tym podmiotem robić interesy, ponieważ jest podmiotem wiarygodnym. Gwarancja bankowa ma więc wartość nie tylko materialną, ale przede wszystkim niematerialną, oddziałując pozytywnie m.in. na: renomę oblata, bezpieczeństwo oferenta i skuteczność w zawieraniu umów z innymi podmiotami, z którymi oblat (dłużnik) dotychczas nie współpracował. Ten instrument finansowy zwiększa pewność w sferze obrotu gospodarczego. Należy podkreślić, że co do zasady rola gwarancji bankowych winna kończyć się wypełnieniem tej funkcji. Dopiero w momencie wystąpienia przez wierzyciela (beneficjenta gwarancji bankowej) $z$ roszczeniem $z$ tytułu gwarancji bank będzie musiał dokonać zapłaty w związku z przyjętym na siebie zobowiązaniem. To spowoduje, że zobowiązanie pozabilansowe takiego banku przekształci się w faktyczny przepływ środków finansowych, doprowadzając do zmian w jego strukturze bilansowej. Dopiero wtedy dochodzi do rozporządzenia mieniem.

Beneficjent gwarancji bankowej, w szczególności tej o charakterze bezwarunkowym, uzyskuje uprzywilejowaną pozycję. Jak podkre-

5 Ibidem. 
ślają przedstawiciele doktryny, „w gwarancjach bezwarunkowych warunki zapłaty są ograniczone. Wystarczające jest zgłoszenie żądania zapłaty, nie ma natomiast potrzeby dokumentowania niewykonania lub nienależytego wykonania zobowiązania zabezpieczonego gwarancją. Przesłanki aktualizacji wykonania gwarancji ograniczają się więc do zgłoszenia przez beneficjenta gwarancji w odpowiedniej formie i w oznaczonym czasie żądania zapłaty o określonej treści. W gwarancjach tego typu wykorzystywane są najczęściej klauzule, w których bank zobowiązuje się wykonać świadczenie pieniężne "bezwarunkowo, na pierwsze żądanie», stąd też gwarancje te określa się niekiedy jako gwarancje na pierwsze żądanie”6. Należy mieć na uwadze, że „na banku-gwarancie lub banku pośredniczącym spoczywa jedynie obowiązek formalnej weryfikacji przedłożonej dokumentacji (lub innych warunków). Bank nie jest zobowiązany do weryfikacji okoliczności stwierdzonych w tych dokumentach"7. Zgodnie $z$ „Jednolitymi regułami dla gwarancji płatnych na żądanie" opracowanymi przez Międzynarodową Izbę Handlową w Paryżu (International Chamber of Commerce) wyłączona jest odpowiedzialność gwaranta za „skuteczność dokumentów” (effectiveness of documents) ${ }^{8}$. „Gwarant nie ponosi odpowiedzialności za: formę, wystarczalność, dokładność, autentyczność, fałszerstwo lub skutek prawny wynikający z dokumentu, który został mu przedstawiony [...]"9. Ten mechanizm redukuje możliwości kontrolne gwaranta w stosunku do beneficjenta. Konstrukcja tego instrumentu finansowego wymusza na banku konieczność sprawnego działania. Siedmiodniowy termin na wypłatę środków wymaga, aby proces decyzyjny w ramach wewnętrznych procedur bankowych opierał się jedynie na przedłożonych przez beneficjenta

${ }^{6}$ B. Smykla, Prawo bankowe. Komentarz, Warszawa 2011, art. 81.

7 T. Grabowski, w: Prawo bankowe. Komentarz, red. H. Gronkiewicz-Waltz, Warszawa 2013, art. 81, M. Olechowski, Glosa do wyroku. SN z 25 czerwca 1999 r., II CKN 402/98, „Orzecznictwo Sądu Najwyższego. Izba Cywilna” 2000, nr 1, poz. 16.

8 Znowelizowane w dniu 1 lipca 2010 r. na podstawie druku URDG 758, Jednolite Reguły dla Gwarancji Ptatnych na Żadanie (URDG 758) wraz z wzorcowymi formularzami, Warszawa 2010.

9 T. Grabowski, w: op.cit. 
dokumentach. Trudno sobie wyobrazić przedstawicieli gwaranta, którzy podejmują działania dotyczące sprawdzenia autentyczności przedłożonego dokumentu odnoszącego się do jakości czy stanu zaawansowania prac będących przedmiotem umowy zabezpieczonej gwarancją bankową, w szczególności w sprawach o dużym stopniu skomplikowania bądź technologicznego zaawansowania. Ta uprzywilejowana pozycja wierzyciela może być kłopotliwa dla dłużnika w przypadku beneficjentów nieuczciwych, którzy nadużyją udzielonego im zaufania, na którym oparta jest konstrukcja bezwarunkowej gwarancji bankowej.

Umowa gwarancji bankowej występuje w praktyce pod różnymi nazwami. Na tę rozbieżność nomenklaturową zwrócono uwagę w doktrynie. „Tendencję do posługiwania się raczej terminem "gwarancja bankowa" aniżeli "umowa gwarancji bankowej" wyjaśnić można tym, iż jest to umowa jednostronnie zobowiązująca. Obowiązek zapłaty obciąża bank, który jest ponadto stroną aktywną przy zawieraniu umowy. Wyraża to wygodny językowo zwrot "udziela gwarancji«. W związku z tym przyjmuje się niekiedy, że stosunek zobowiązaniowy gwarancji kreowany jest przez jednostronne oświadczenie banku - a nie przez umowę. Temu stanowi zamieszania terminologicznego sprzyjają także sformułowania zawarte w Prawie bankowym. Artykuły 81, 82 i 87 Prawa bankowego, normujące omawianą materię, posługują się określeniami "gwarancja" lub "gwarancja bankowa". Nie używają natomiast pojęcia "umowa gwarancji bankowej". To ostatnie jest natomiast stosowane w literaturze - chociaż często zamiennie $z$ "gwarancją bankową". Nazwa ta używana też bywa niekiedy jako określenie zbiorcze, obejmujące całokształt stosunków zobowiązaniowych, w związku z którymi powstaje ciążący na banku obowiązek spełnienia świadczenia gwarancyjnego. Są to stosunki zachodzące w relacjach: gwarant-beneficjent, gwarant-dłużnik stosunku podstawowego oraz dłużnik stosunku podstawowego-wierzyciel (beneficjent)" ${ }^{\prime 10}$.

Dla zachowania w niniejszej publikacji jednolitości terminologicznej nazwa „umowa gwarancji bankowej” będzie używana w zna-

10 A. Koch, w: Prawo bankowe. Komentarz, red. J. Panowicz-Lipska, Warszawa 2011 , art. 81. 
czeniu ścisłym, w odniesieniu do czynności prawnej zawieranej pomiędzy podmiotem zabiegającym o uzyskanie gwarancji bankowej a bankiem, odgrywającym rolę gwaranta. Natomiast termin "gwarancja bankowa” odnoszony będzie do całokształtu stosunków zobowiązaniowych, w związku z którymi powstaje ciążący na banku obowiązek spełnienia świadczenia gwarancyjnego, a które zachodzą w relacjach: gwarant-beneficjent, gwarant-dłużnik oraz dłużnik-beneficjent.

\section{Nieprawidłowości na etapie zabiegania o ustanowienie gwarancji bankowej}

Stosunki zobowiązaniowe wynikające $z$ gwarancji bankowej mają charakter wielostronny. Jak wskazano wcześniej, zachodzą w relacjach: gwarant (bank udzielający gwarancji)-beneficjent (wierzyciel stosunku podstawowego), gwarant (bank udzielający gwarancji)-dłużnik (również dłużnik stosunku podstawowego) oraz dłużnik-beneficjent (wierzyciel stosunku podstawowego). Uzyskanie gwarancji bankowej leży w interesie beneficjenta, który jako wierzyciel stosunku podstawowego może żądać od dłużnika zabezpieczenia swoich interesów, np. w formie gwarancji bankowej. Co do zasady, choć to wierzyciel stosunku podstawowego inicjuje działania zabezpieczające, to jednak o tę gwarancję do banku nie występuje. O uzyskanie gwarancji bankowej zabiegać musi podmiot zobowiązany wobec beneficjenta, czyli dłużnik stosunku podstawowego, który po uzyskaniu tego zabezpieczenia staje się również dłużnikiem banku. To właśnie na zlecenie dłużnika stosunku podstawowego dochodzi do zawarcia $z$ bankiem umowy gwarancji bankowej. Nie oznacza to jednak, że beneficjent nie ma wpływu na tę czynność. To przecież on umawia się $z$ dłużnikiem na określoną formę zabezpieczenia i decyduje o jej przyjęciu bądź odrzuceniu. Występujące zależności pozwalają na stwierdzenie, że skuteczność ustanowienia gwarancji bankowej wymaga zgodnej kooperacji wszystkich podmiotów: gwaranta, dłużnika i beneficjenta.

Biorąc pod uwagę relacje występujące pomiędzy podmiotami zainteresowanymi ustanowieniem gwarancji bankowej należy uznać, że 
zarówno dłużnik, jak i beneficjent zaliczają się do podmiotów, które zabiegają o uzyskanie tego zabezpieczenia finansowego, a mianowicie beneficjent za pośrednictwem dłużnika, a dłużnik bezpośrednio u gwaranta. Oznacza to, że działania obu tych podmiotów podejmowane są w celu uzyskania gwarancji bankowej. W przypadku wystąpienia nieprawidłowości na etapie zabiegania o udzielenie gwarancji bankowej zarówno dłużnik, jak i beneficjent mogą zostać zaliczeni do kręgu osób zdolnych do poniesienia odpowiedzialność na podstawie art. $297 \S 1 \mathrm{k} . \mathrm{k}$. Zgodnie $z$ brzmieniem tego przepisu jest on adresowany do osób, które w celu uzyskania dla siebie lub kogo innego, określonego instrumentu finansowego (wsparcia finansowego, instrumentu płatniczego lub zamówienia) od banku lub jednostki organizacyjnej prowadzącej podobną działalność gospodarczą na podstawie ustawy albo od organu lub instytucji dysponujących środkami publicznymi, przedkładają podrobiony, przerobiony, poświadczający nieprawdę albo nierzetelny dokument albo nierzetelne, pisemne oświadczenie dotyczące okoliczności o istotnym znaczeniu dla uzyskania wymienionego instrumentu finansowego. Obok gwarancji ustawodawca wymienił wśród tych instrumentów również kredyt, pożyczkę pieniężną, poręczenie, akredytywę, dotację, subwencję, potwierdzenie przez bank zobowiązania wynikającego $z$ poręczenia lub $z$ gwarancji lub podobne świadczenia pieniężne na określony cel gospodarczy. Występek $z$ art. 297 § 1 k.k. zagrożony jest karą pozbawienia wolności od 3 miesięcy do lat 5 .

Na potrzeby tej publikacji wymieniony w tym przepisie katalog fałszywych i nierzetelnych dokumentów i oświadczeń zawarty będzie w terminie „fałszywe dokumenty”.

Na etapie zabiegania o udzielenie gwarancji bankowej fałszywymi dokumentami posłużyć się mogą oba te podmioty. Dłużnik może posłużyć się fałszywymi dokumentami, składając je bezpośrednio w banku, w którym zabiega o uzyskanie gwarancji bankowej, jak również beneficjent za pośrednictwem nieświadomego albo współdziałającego $z$ nim dłużnika może dostarczyć gwarantowi dokumenty, które nie odzwierciedlają rzeczywistych zdarzeń gospodarczych. Nie można wykluczyć sytuacji, że przyszły beneficjent zakłada wyłudzenie środków finansowych $z$ tytułu gwarancji bankowej i aby to osiągnąć, nakłania dłużnika, by ten zabezpieczył ich 
relację biznesową tego typu instrumentem finansowym. Sprawca może chcieć skorzystać ze sposobności, jaką będzie mu stwarzała pozycja podmiotu uprawnionego do żądania zapłaty przy użyciu tego instrumentu finansowego. W tej sytuacji może dojść do przekazania dłużnikowi fałszywych dokumentów, które ten uzna za autentyczne i posłuży się nimi w banku, nie mając świadomości ich wadliwości. W tym przypadku to beneficjent, a nie wierzyciel działający w błędzie, będzie ponosił odpowiedzialność za nieprawidłowości w procesie uzyskiwania gwarancji bankowej.

\section{Nieprawidłowości na etapie żądania wypłaty środków z tytułu gwarancji bankowej}

Odmiennie kształtują się uprawnienia podmiotów po zawarciu umowy gwarancji bankowej, ponieważ tylko beneficjent jest uprawniony do żądania zapłaty ze środków gwarantowanych tym zabezpieczeniem finansowym. Ewentualne nieprawidłowości związane $z$ procedurą uruchamiania wypłaty środków $z$ tytułu gwarancji bankowej obciążałyby więc już tylko beneficjenta, a nie dłużnika. Kwestią kluczową jest ustalenie, czy działania podejmowane już po ustanowieniu gwarancji bankowej mogą być zakwalifikowane $z$ art. $297 \S 1$ k.k. Jej rozstrzygnięcie wymaga ustalenia, czy termin „uzyskanie gwarancji” stanowiący znamię tego przestępstwa obejmuje swoim znaczeniem również działania zmierzające do uzyskania środków zabezpieczonych uzyskaną już gwarancją bankową.

Jak trafnie zauważył Robert Zawłocki, karalność za dokonanie oszustwa finansowego przesunięto na przedpole czynu stanowiącego znamiona klasycznego oszustwa. „Jest to konstrukcja powiązana ze szczególnym ujęciem przedmiotu ochrony, którym jest zapewnienie prawidłowego funkcjonowania określonych instytucji gospodarczych i ochronie pokładanego w nich zaufania. W konsekwencji dochodzi tu do "skrócenia" warunków penalizacji, co ma na celu ograniczenie problemów dowodowych występujących przy klasycz- 
nym oszustwie"11. To przesunięcie może wywoływać pewne obawy dotyczące temporalnych ograniczeń oddziaływania tego przepisu. Wśród znamion przestępstwa stypizowanego w art. $297 \S 1$ k.k. znajduje się element kierunkowy, określony jako działanie „w celu uzyskania gwarancji”. Powstaje więc pytanie, czy odpowiedzialności na podstawie tego przepisu może podlegać tylko podmiot operujący na etapie poprzedzającym zawarcie umowy gwarancji bankowej czy też dotyczy on również osób podejmujących działania w etapach późniejszych i obejmuje swoimi granicami także działania zmierzające do uzyskania środków finansowych przez beneficjenta $z$ tytułu gwarancji bankowej. W doktrynie nie ma wątpliwości, że działanie sprawcy polegające na przedkładaniu fałszywych dokumentów dotyczących okoliczności istotnych dla uzyskania dostępu do jednego $\mathrm{z}$ instrumentów finansowych wymienionych w przepisie art. 297 $\S 1$ k.k., czyli na etapie zabiegania o ustanowienie gwarancji bankowej, wyczerpuje znamiona tego przestępstwa ${ }^{12}$. Kwestia ta staje się mniej oczywista, gdy na etapie zabiegania o dostęp do gwarancji bankowej nie doszło do nieprawidłowości, ale fałszywym dokumentem posłużono się później - na etapie zabiegania o uruchomienie środków finansowych $z$ tytułu ustanowionej gwarancji bankowej.

Sposobność, jaką jest status beneficjenta gwarancji bankowej o charakterze bezwarunkowym, może stanowić przyczynę podjęcia działań przestępnych zmierzających do uzyskania środków zabezpieczonych w ramach tego instrumentu finansowego. Jak wykazano w poprzedniej części artykułu, ten mechanizm pozwala na bezproblemowe sięgnięcie przez beneficjenta po środki finansowe zabezpieczone gwarancją bankową przy użyciu fałszywego dokumentu. Beneficjent gwarancji bankowej, w szczególności tej o charakterze bezwarunkowym, może wykorzystać swoją uprzywilejowaną pozycję, wynikającą $z$ braku weryfikacji przedkładanych przez niego dokumentów i wystąpić z nieuprawnionym żądaniem uruchomienia zabezpieczenia. W przypadku nieuczciwych beneficjentów może dojść do nadużycia udzielonego im zaufania, na którym opiera się

11 J. Bojarski, T. Oczkowski, w: Komentarz do Kodeksu karnego, red. R. Zawłocki, Warszawa 2015, s. 544.

12 Ibidem, s. 541. 
konstrukcja bezwarunkowej gwarancji bankowej. To niezgodne z prawem działanie ze strony wierzyciela może spowodować, że zobowiązanie pozabilansowe banku przekształci się w faktyczny przepływ środków finansowych, doprowadzając do rozporządzenia mieniem, które wywoła zmiany w jego aktywach.

Według Janusza Bojarskiego i Tomasza Oczkowskiego wykładnia znamion strony przedmiotowej przestępstwa $z$ art. $297 \S 1$ k.k. prowadzi do wniosku, że czynności wykonawcze mogą być realizowane przez sprawcę również w toku wszczętej procedury. Autorzy ci w komentarzu do Kodeksu karnego podkreślili, że chodzi tu o każdy etap związany $z$ wszczęciem i prowadzeniem procedury mającej na celu ocenę, czy dana instytucja może być udzielona lub przyznana ${ }^{13}$. Pozwala to na przyjęcie, że posłużenie się fałszywym dokumentem w okresie poprzedzającym uzyskanie dostępu do środków finansowych będzie wyczerpywało znamiona oszustwa kredytowego. Specyfika gwarancji bankowej pozwala na wyróżnienie przynajmniej dwóch etapów procedury jej uzyskiwania. Pierwszy zmierzający do uzyskania jednostronnego zobowiązania ze strony gwaranta i drugi związany z uruchomieniem żądania zapłaty ze środków, których limity zostały określone w umowie gwarancji bankowej. Odnosząc się do zasygnalizowanej specyfiki tego instrumentu finansowego pod pojęciem „uzyskanie gwarancji”, o którym mowa w art. 297 § 1 k.k., należy rozumieć zarówno uzyskanie na podstawie fałszywych dokumentów jednostronnego zobowiązania ze strony gwaranta, jak i uzyskanie przez beneficjenta środków zagwarantowanych umową. Na marginesie należy podkreślić, że nie jest przy tym istotna liczba tych fałszywych dokumentów. Jak trafnie zauważył Sąd Apelacyjny w Łodzi w wyroku z 26 lipca 2000 r., do zaistnienia przestępstwa oszustwa kredytowego wystarczy, że starający się o kredyt przedstawi choć jeden fałszywy lub stwierdzający nieprawdę dokument, choć jedno nierzetelne oświadczenie ${ }^{14}$. Posłużenie się fałszywym dokumentem na którymkolwiek $z$ wymienionych etapów, będzie wyczerpywało znamiona przestępstwa $z$ art. $297 \S 1$ k.k.

13 Ibidem, s. 544.

14 Wyrok SA w Łodzi z 26 lipca 2000 r., I Aka 93/00, Legalis. 
Zaprezentowaną tezę dodatkowo wzmacnia argumentacja odnosząca się do znamienia przestępstwa oszustwa kredytowego, jakim jest przedmiot ochrony. Jacek Potulski trafnie zauważa, że finalnym efektem oszustwa kredytowego jest uszczuplenie finansów banku, które powoduje konieczność zwiększania marży banku stosowanej wobec każdego klienta oraz zaostrzenie poziomu zabezpieczeń $\mathrm{kredytu}^{15}$. Tego typu zachowania godzą w stabilności procesów inwestycyjnych, a co za tym idzie - w stabilność rynku pracy ${ }^{16}$. Według Bojarskiego i Oczkowskiego istota prawnokarnej ochrony wynikającej $z$ art. 297 § 1 k.k. w przypadku instytucji bankowych polega na zabezpieczeniu ich prawidłowego funkcjonowania ze wskazaniem, że nieprawidłowości w procesie ich udzielania mogą stwarzać zagrożenie dla całego lub części systemu bankowego ${ }^{17}$. Niewątpliwie takie zagrożenie wywołują działania, które mogą doprowadzić do wyprowadzenia środków z systemu bankowego, a więc te, które mogą wywołać skutek bilansowy. Sąd Najwyższy w orzeczeniu z 7 marca 2013 r. stwierdził, że składne przez sprawcę oświadczenie musi dotyczyć okoliczności o istotnym znaczeniu dla uzyskania wymienionych w art. $297 \S 1$ k.k. form wsparcia finansowego ${ }^{18}$. Wynika $z$ tego, że celem sprawcy przedkładającego fałszywy albo nierzetelny dokument (oświadczenie) może być nie tylko uzyskanie zabezpieczenia, które poprawia wiarygodność kontrahenta w oczach wierzyciela, ale jest nim przede wszystkim dążenie do uzyskania konkretnego wsparcia finansowego wynikającego $z$ umowy gwarancji bankowej. Nie jest istotną okolicznością, z punktu ponoszenia odpowiedzialności wynikającej $z$ tego przepisu, że nie doszło do nieprawidłowości w etapie zabiegania o ustanawianie gwarancji bankowej. Posłużenie się fałszywym dokumentem w związku z żądaniem zapłaty $z$ tytułu ustanowionej gwarancji bankowej będzie wyczerpywać znamiona przestępstwa określonego w art. $297 \S 1$ k.k.,

15 J. Potulski, Kodeks karny. Komentarz, red. R. Stefański, Warszawa 2017, art. 297.

16 Ibidem.

17 Ibidem. s. 537.

18 Postanowienie SN - Izba Karna z dnia 7 marca 2013 r., V KK 304/12, Legalis. 
bez względu na to czy zapłata na rzecz beneficjenta nastąpiła, czy też odmówiono jej dokonania.

Należy podkreślić, że zaistnienie skutku w postaci wypłaty środków beneficjentowi na podstawie umowy gwarancji bankowej nie należy do znamion przestępstwa oszustwa kredytowego. Jak podkreśla się w doktrynie, „przestępstwo oszustwa kredytowego ma charakter formalny [...]. Nie ma tu więc także znaczenia, czy na skutek działania sprawcy, podmiot udzielający określonej instytucji gospodarczej poniesie $z$ tego powodu szkodę majątkową, jest ono bowiem dokonane $\mathrm{z}$ chwilą przedłożenia określonego $\mathrm{w}$ tym przepisie dokumentu lub oświadczenia"19. Stanowisko to znalazło akceptację w judykaturze. Między innymi w wyroku Sądu Apelacyjnego we Wrocławiu z 25 marca 2014 r. stwierdzono, że przestępstwo określone w art. $297 \mathrm{k} . \mathrm{k}$. to przestępstwo o charakterze formalnym, a wymieniony przepis służy do kryminalizacji zachowań na przedpolu naruszenia dóbr prawnych chronionych przez art. 286 k.k. W uzasadnieniu tego orzeczenia potwierdzono, że dla jego realizacji nie jest konieczne wystąpienie skutku w postaci uzyskania kredytu, a tym bardziej zaistnienia szkody majątkowej ${ }^{20}$.

\section{Podsumowanie}

Z przeprowadzonej analizy wynika, że znamię kierunkowe przestępstwa, o którym mowa w art. 297 § 1 k.k. odnoszące się do działania „w celu uzyskania gwarancji”, dotyczy wszystkich etapów poprzedzających wypłatę środków finansowych zabezpieczonych gwarancją bankową. Zachowania polegające na posłużeniu się fałszywymi dokumentami w trakcie zabiegania o ustanowienie tego zabezpieczenia oraz wypłatę środków $z$ tego instrumentu finansowego mieszczą się w granicach analizowanego znamienia i jako godzące w obrót gospodarczy mogą być kwalifikowane $z$ art. 297 § 1 k.k. Zaprzeczono więc przyjętej hipotezie, że ewentualne nieprawidłowości po uzyskaniu gwarancji bankowej, na późniejszych etapach związanych z wykony-

19 J. Bojarski, T. Oczkowski, op.cit, s. 544.

20 Wyrok SA we Wrocławiu z 25 marca 2014 r., II AKa 49/14, Legalis. 
waniem umowy statuującej ten rodzaj zabezpieczenia, nie mogą być uznane za działania podjęte w celu uzyskania gwarancji bankowej. Przyjęte stanowisko znajduje dodatkowe potwierdzenie w argumentacji odnoszącej się do przedmiotu ochrony omawianego przepisu karnego. Zagrożenia dla całego lub części systemu bankowego występują w sytuacjach wyprowadzania środków $\mathrm{z}$ tego sytemu. Nieracjonalne byłoby działanie ustawodawcy, który reagowałby na działania dotyczące sfery pozabilansowej, a pozostawiłby bezkarne zachowania bezpośrednio zmierzające do wyprowadzenia środków $z$ systemu bankowego. Zasadne jest więc przyjęcie, że działania, które zmierzają do wystąpienia tego skutku, bez względu na etap, w którym są podejmowane, mogą wyczerpywać znamiona oszustwa kredytowego. Konsekwencją dokonanego ustalenia jest uznanie, że podmiotem przestępstwa $z$ art. $297 \S 1$ k.k. może być nie tylko dłużnik zabiegający w banku o uzyskanie gwarancji bankowej, ale również wierzyciel, którego interesy zostały zabezpieczone tym instrumentem finansowym.

\section{STRESZCZENIE}

Gwarancja bankowa jako przedmiot czynności wykonawczej w oszustwie kredytowym

Przestępstwo oszustwa kredytowego przewidzianego w art. 297 § 1 k.k. jest przedstawiane przez autorów licznych komentarzy przez pryzmat nieprawidłowości występujących w umowach kredytowych. Całkowicie pomijają oni problematykę gwarancji bankowych lub poprzestają jedynie na zdefiniowaniu tego instrumentu finansowego. Różnice, które występują pomiędzy mechanizmami kredytowymi i gwarancyjnymi nie pozwalają na bezpośrednie stosowanie rozwiązań pasujących do jednego $z$ tych instrumentów finansowych do drugiego. W publikacji podjęto próbę wskazania tych różnic i ustalenia zakresu stosowania przepisu art. $297 \S 1$ k.k. w odniesieniu do gwarancji bankowej. W artykule przedstawiono wyniki badań, które przeprowadzono $\mathrm{z}$ wykorzystaniem metod badawczych stosowanych w naukach prawnych.

Słowa kluczowe: oszustwo kredytowe; znamiona przestępstwa; przedmiot czynności wykonawczej; gwarancja bankowa 


\section{SUMMARY}

\section{Bank guarantee as an element of credit fraud crime}

Credit fraud crime provided for in article $297 \S 1$ of Polish Criminal Code is presented by the authors of the numerous comments by the prism of irregularities in credit agreements. They completely ignore the issue of bank guarantees or settle down only on the defining it as the financial instrument. The differences that exist between the credits and guarantees mechanisms do not allow for the direct application of solutions that match one of these financial instruments to the second financial instrument. In the publication author indicate these differences and the scope of application of the gist of article $297 \S 1$ of Polish Criminal Code in respect of a bank guarantee. The article presents the results of a research that was conducted with the use of research methods used in law sciences.

Keywords: credit fraud crime; elements of the offence; legal goods; bank guarantee

\section{BIBLIOGRAFIA}

Bojarski J., Oczkowski T., w: Komentarz do Kodeksu karnego, red. R. Zawłocki, Warszawa 2015.

Grabowski T., w: Prawo bankowe. Komentarz, red. H. Gronkiewicz-Waltz, Warszawa 2013.

Koch A., w: Prawo bankowe. Komentarz, red. J. Panowicz-Lipska, Warszawa 2011 , Legalis.

Olechowski M., Glosa do wyroku. SN z 25 czerwca 1999 r., II CKN 402/98, Orzecznictwo Sądu Najwyższego. Izba Cywilna 2000, nr 1, poz. 16.

Potulski J., w: Kodeks karny. Komentarz, red. R. Stefański, Warszawa 2017. Sikorski G., Prawo bankowe. Komentarz, Warszawa 2015.

Smykla B., Prawo bankowe. Komentarz, Warszawa 2011. 